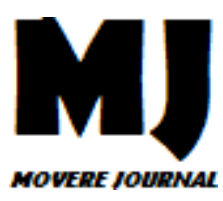

Movere Journal Vol 3 No. 1 Januari 2021 Hal 1 - 16

MOVERE JOURNAL

http://ojs.stie-tdn.ac.id/index.php/mv

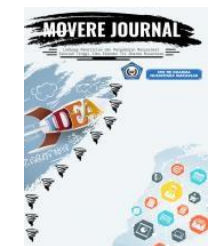

\title{
PENGARUH GAYA KEPEMIMPINAN TERHADAP KINERJA KARYAWAN PADA PT. PELINDO IV (PERSERO) CABANG MAKASSAR.
}

Tri Sulkanain Ahmad ${ }^{1}$, Andi Muhammad Ramadhan Thamrin². Universitas Tomakaka Mamuju Sulawesi Barat

\begin{abstract}
Abstrak : Penelitian ini bertujuan untuk mengetahui pengaruh gaya kepemimpinan terhadap kinerja karyawan pada PT. Pelindo IV (Persero) Cabang Makassar. Jenis data yang digunakan adalah data kualitatif dan data kuantitatif. Sumber data yang digunakan yaitu data primer dan sekunder. Metode analisis yang digunakan adalah deskriptif dan regresi linear sederhana, koefisien korelasi, koefisien determinasi, serta uji t. hasil penelitian menunjukkan $\mathrm{Y}=10,200+$ 0,754X, kemudian nilai koefisien korelasi (r) sebesar 0,891 dan koefisien determinasi $\left(r^{2}\right)$ sebesar 0,79 atau 79\%. Perhitungan uji-t didapatkan hasil $t_{\text {hitung }}>t_{\text {tabel }}(14,913>1,671)$ maka diketahui bahwa $\mathrm{H}_{\mathrm{o}}$ ditolak dan $\mathrm{H}_{\mathrm{a}}$ diterima. Hasil penelitian menunjukkan terdapat hubungan positif dan signifikan antara gaya kepemimpinan terhadap kinerja karyawan PT. Pelindo IV (Persero) Cabang Makassar, dengan demikian hipotesis yang diajukan diterima.
\end{abstract}

Kata kunci: Gaya kepemimpinan, kinerja karyawan.

Abstract : This study aims to determine the influence of leadership style on the performance of employees at PT. Pelindo IV (Ltd.) Makassar Branch. This research used qualitative data and quantitative data. Data sources used are primary and secondary data. The analysis method used is descriptive and simple linear regression, correlation coefficient, determination $n$ coefficient, and t test. The result shows $Y=10,200+0.754 X$, then the correlation coefficient $(r)$ is 0.891 and the coefficient of determination $\left(r^{2}\right)$ in the amount of 0.79 or $79 \%$. The t-test calculation shows the results of $t$ count $>t$ table (14.913> 1.671). Then, it is known that Ho is rejected and Ha is accepted. The results of the research show that there is a positive and significant relation between leadership style to the employees' performance at PT. Pelindo IV (Ltd.), Makassar Branch, thus the hypothesis is accepted.

Keywords: leadership style, employee performance 


\section{PENDAHULUAN}

\section{A. Rumusan Masalah}

Gaya kepemimpinan merupakan norma perilaku yang digunakan oleh seorang pada saat orang tersebut mencoba mempengaruhi perilaku orang lain seperti yang ia lihat. Dalam hal ini usaha menyelaraskan persepsi di antara orang yang akan memengaruhi perilaku dengan orang yang perilakunya akan dipengaruhi menjadi amat penting kedudukannya.

Dalam sebuah perusahaan, gaya kepemimpinan seorang pimpinan merupakan hal yang perlu diperhatikan. Kepemimpinan dalam sebuah organisasi dituntut untuk bisa membuat individuindividu yang dipimpinnya bisa berperilaku sesuai yang diinginkan oleh pemimpin untuk mencapai tujuan perusahaan. Oleh karena itu seorang pemimpin dituntut untuk memahami perilaku setiap individu yang ada di perusahaannya dan menemukan gaya kepemimpinan yang tepat bagi perusahaannya. Gaya kepemimpinan diduga akan sangat mempengaruhi kondisi kerja, dimana akan berhubungan dengan bagaimana karyawan menerima suatu gaya kepemimpinan, senang atau tidak, suka atau tidak. Di satu sisi gaya kepemimpinan tertentu dapat menyebabkan peningkatan kinerja di sisi lain dapat menyebabkan penurunan kinerja suatu perilaku seseorang individu ketika melakukan kegiatan pengarahan suatu kelompok ke arah pencapaian tertentu.

Hubungannya dengan perilaku pemimpin, ada dua hal yang biasanya dilakukan pemimpin terhadap bawahannya, yakni: perilaku mengarahkan dan perilaku mendukung. Perilaku mengarahkan dapat dirumuskan sebagai sejauh mana seorang pemimpin melibatkan diri dalam komunikasi satu arah, sedangkan perilaku mendukung adalah sejauh mana seorang pemimpin melibatkan diri dalam komunikasi dua arah, misalnya mendengar, menyediakan dukungan dan dorongan, memudahkan interaksi, dan melibatkan para pengikut dalam pengambilan keputusan.

Kinerja karyawan merupakan salah satu faktor utama yang dapat memengaruhi kemajuan perusahaan. Semakin tinggi atau semakin baik kinerja karyawan maka tujuan perusahaan akan semakin mudah dicapai, begitu pula sebaliknya yang terjadi apabila kinerja karyawan rendah atau tidak baik maka tujuan itu akan sulit untuk dicapai dan juga hasil yang diterima tidak sesuai dengan keinginan perusahaan.

Kekuatan setiap perusahaan adalah terletak pada setiap individunya, sehingga prestasi suatu perusahaan tidak terlepas dari prestasi setiap individu yang terlihat di dalamnya. Kinerja karyawan pada dasarnya merupakan hasil kerja seorang karyawan selama periode tertentu dibandingkan dengan berbagai kemungkinan, misalnya standar, target, sasaran atau kriteria yang telah ditentukan terlebih dahulu dan disepakati bersama. Seorang karyawan akan merasa mempunyai kebanggaan dan kepuasan tersendiri dengan prestasi dari yang dicapai berdasarkan kinerja yang diberikannya pada perusahaan. Kinerja yang baik merupakan keadaan yang diinginkan dalam dunia kerja. 
PT. Pelindo IV (Persero) Cabang Makassar merupakan sebuah perusahaan negara yang bergerak di bidang jasa kepelabuhanan. Perusahaan ini merupakan perusahaan negara yang selalu mendapat profit yang meningkat tiap tahunnya dan kesejahteraan para karyawannya pun selalu terjamin. Berangkat dari situlah penulis tertarik untuk meneliti perusahaan tersebut, faktor apa yang menyebabkan kinerja para karyawan di PT. Pelindo IV (Persero) Cabang Makassar selalu mencapai atau melampaui target perusahaan di tiap tahunnya.

\section{B. Rumusan Masalah}

Berdasarkan uraian latar belakang dikemukakan rumusan dalam penelitian ini, "apakah gaya kepemimpinan berpengaruh terhadap kinerja karyawan pada PT. Pelindo IV (Persero) Cabang Makassar ?"

\section{Tujuan Penelitian}

Adapun tujuan yang ingin dicapai dari penelitian ini adalah untuk mengetahui pengaruh gaya kepemimpinan terhadap kinerja karyawan di PT. Pelindo IV (Persero) Cabang Makassar.

\section{TINJUAN PUSTAKA}

\section{A. Gaya Kepemimpinan}

Gaya kepemimpinan merupakan "Norma perilaku yang digunakan oleh seseorang pada saat orang tersebut mencoba memengaruhi perilaku orang lain seperti yang ia lihat" (Thoha, 2017:49), sedangkan pendapat lain "Gaya kepemimpinan adalah gaya yang digunakan manajer untuk mempengaruhi, mengatur, dan mengkoordinasikan karyawan (bawahan) dalam rangka mencapai tujuan perusahaan yang efektif" (Sadariah, 2016:12), serta pendapat ahli yang lain "Gaya kepemimpinan adalah cara seseorang pemimpinan mempengaruhi perilaku bawahan, agar mau bekerja sama dan bekerja produktif untuk mencapai tujuan organisasi" (Hasibuan, 2017:170)

Seorang pemimpin dalam menjalankan tugas pastinya memiliki gaya kepemimpinannya masing-masing. Begitu juga satu perusahaan dengan perusahaan yang lain biasanya membutuhkan gaya kepemimpinan yang berbeda. Seorang pemimpin harus mengetahui situasi maupun kondisi dalam suatu perusahaan, seperti sistem yang digunakan dan juga target yang ingin dicapai sebelum memutuskan gaya kepemimpinan yang paling baik digunakan.

Kesimpulan bahwa gaya kepemimpinan merupakan cara, pola atau kemampuan tertentu dari masing-masing pemimpin dalam berkomunikasi, berinteraksi dan bersikap untuk memengaruhi, mengendalikan dan mendorong para bawahan atau karyawannya agar bisa melakukan suatu pekerjaan dan mencapai tujuan organisasi.

\section{Jenis - jenis gaya kepemimpinan}

Gaya kepemimpinan pada dasarnya dapat dilihat dari bermacammacam sudut pandangan. Menurut Hasibuan (2017:172) ,macam gaya kepemimpinan ada 4, yaitu:

a. Gaya Kepemimpinan otoriter adalah jika kekuasaan atau wewenang, sebagian besar mutlak berada pada pimpinan atau kalau pimpinan itu menganut sistem sentralisasi 
wewenang. Pengambilan keputusan dan kebijaksanaan hanya ditetapkan sendiri oleh pemimpin, bawahan tidak diikutsertakan untuk memberikan saran ide, dan pertimbangan dalam proses pengambilan keputusan.

b. Gaya Kepemimpinan partisipatif adalah apabila dalam kepemimpinannya dilakukan dengan cara persuasif, menciptakan kerja sama yang serasi, menumbuhkan loyalitas, dan partisipasi bawahan. Pemimpin memotivasi bawahan agar ikut memiliki perusahaan.

c. Gaya kepemimpinan delegatif apabila seorang pemimpin mendelegasikan wewenang kepada bawahan dengan agak lengkap. Dengan demikian, bawahan dapat mengambil keputusan dan kebijaksanaan dengan bebas atau leluasa dalam melaksanakan pekerjaannya. Pemimpin tidak peduli cara bawahan mengambil keputusan, sepenuhnya diserahkan kepada bawahan. Pada prinsipnya pemimpin bersikap menyerahkan, dan mengatakan kepada bawahan "Silahkan dikerjakan asal baik hasilnya"

d. Gaya kepemimpinan situasional Model ini dikembangkan oleh Paul Hersey dan Kenneth H. Blanchard di pusat Studi Kepemimpinan pada akhir tahun 1960, hingga tahun 1982. Hersey \& Blanchard bekerja sama secara kontinu menyempurnakan kepemimpinan situasional. Menurut kepemimpinan situasional, tidak ada satu pun cara yang terbaik untuk mempengaruhi orang lain. Gaya kepemimpinan mana yang harus digunakan terhadap individu atau kelompok tergantung pada tingkat kesiapan orang yang dipengaruhi.

Maka dapat disimpulkan bahwa setiap pemimpin pasti mempunyai gaya kepemimpinan yang dimilikinya sendiri, semua itu tergantung dari pemimpin itu sendiri benar atau tidaknya cara mereka menggunakan gayanya terhadap para bawahannya yang bermacam-macam sikap dan sifat.

\section{Indikator Gaya Kepemimpinan}

Seorang pemimpin dapat dikatakan baik apabila dapat membuat karyawannya mengikuti apa yang diarahkannya demi tujuan perusahaan.

Berikut indikator gaya kepemimpinan menurut Kartono (2018:34) "Adalah sifat, kebiasaan, tempramen, watak, dan kepribadian sendiri yang unik dan khas sehingga tingkah laku dan gayanya yang membedakan dirinya dan orang lain" yaitu : a) Sifat, b) Kebiasaan, c) Tempramen, d) Watak, e) Kepribadian.

\section{B. Kinerja}

Kinerja adalah hasil kerja dan perilaku kerja yang telah dicapai dalam menyelesaikan tugas-tugas dan tanggung jawab yang diberikan dalam suatu periode tertentu" (Kasmir, 2016:182). "Kinerja karyawan (prestasi kerja) adalah hasil kerja secara kualitas dan kuantitas yang dicapai oleh seseorang karyawan dalam melaksanakan tugasnya sesuai dengan tanggung jawab yang diberikan kepadanya" (Mangkunegara, 2017:9).

Dari pendapat beberapa ahli di atas, dapat disimpulkan bahwa penilaian kinerja merupakan suatu proses yang dilakukan secara sistematis untuk menilai keseluruhan kinerja pegawai 
dalam jangka waktu atau periode tertentu. Kegunaan penilaian kinerja merupakan sebuah mekanisme yang dapat digunakan untuk memastikan apakah setiap karyawan pada tiap tingkatan telah menyelesaikan tugasnya sesuai dengan standar yang ditetapkan sebelumnya.

\section{Faktor-faktor kinerja}

Menurut Kasmir (2016:189) faktor-faktor yang mempengaruhi kinerja baik hasil maupun perilaku, yaitu sebagai berikut:

a. Kemampuan Merupakan kemampuan atau skill yang dimiliki seseorang dalam melakukan suatu pekerjaan. Semakin memiliki kemampuan dan keahlian maka akan dapat menyelesaikan pekerjaannya secara benar, sesuai dengan yang telah ditetapkan.

b. Pengetahuan, Maksudnya adalah pengetahuan tentang pekerjaan. Seseorang yang memiliki pengetahuan tentang pekerjaan secara baik akan memberikan hasil pekerjaan yang baik, demikian pula sebaliknya.

c. Rancangan kerja Merupakan rancangan pekerjaan yang akan memudahkan karyawan dalam mencapai tujuannya. Artinya jika sesuatu pekerjaan memiliki rancangan yang baik, maka akan memudahkan untuk menjalankan pekerjaan tersebut secara tepat dan benar, dan sebalinya pun begitu.

d. Kepribadian Yaitu kepribadian seseorang atau karakter yang dimiliki seseorang. Setiap orang memilki kepribadian atau karakter yang berbeda satu sama lainnya. Seseorang yang memiliki kepribadian atau karakter yang baik, akan dapat melakukan pekerjaan secara sungguh-sungguh penuh tanggung jawab sehingga hasil pekerjaanya juga baik, demikian pula sebaliknya.

e. Motivasi kerja, Motivasi kerja merupakan dorongan bagi seseorang untuk melakukan pekerjaan. Jika karyawan memiliki dorongan yang kuat dari dalam dirinya atau dorongan dari luar dirinya (misalnya dari pihak perusahaan), maka karyawan akan terangsang atau terdorong untuk melakukan sesuatu dengan baik. Tetapi bila karyawan itu sendiri tidak memiliki motivasi apapun, dipastikan kinerjanya hanya begitubegitu saja dan cenderung menurun.

f. Kepemimpinan merupakan perilaku seseorang pemimpin dalam mengatur, mengelola, dan memerintah bawahannya untuk mengerjakan sesuatu tugas dan tanggung jawab yang diberikannya. Sebagai contoh perilaku pemimpin yang menyenangkan, mengayomi, mendidik, dan membimbing tentu akan membuat karyawan senang dengan mengikuti apa yang diperintahkan oleh atasannya.

g. Gaya kepemimpinan, Merupakan gaya atau sikap seorang pemimpin dalam menghadapi atau memerintahkan bawahannya. Sebagai contoh gaya atau sikap seorang pemimpin yang demokratis tentu berbeda dengan gaya kepemimpinan yang otoriter. Dalam praktiknya gaya kepemimpinan ini dapat diterapkan sesuai dengan kondisi organisasinya. 
h. Budaya organisasi Merupakan kebiasaan-kebiasaan atau normanorma yang berlaku dan dimiliki oleh suatu organisasi atau perusahaan. Kebiasaan-kebiasaan atau norma-norma ini mengatur hal-hal yang berlaku dan diterima secara umum serta harus dipatuhi oleh segenap anggota suatu perusahaan atau organisasi. Kepatuhan anggota organisasi untuk menuruti atau mengikuti kebisaan atau norma ini akan memengaruhi kinerja seseorang atau organisasi.

i. Kepuasan kerja Merupakan perasaan senang atau gembira, atau perasaan suka seseorang sebelum dan setelah melakukan suatu pekerjaan. Jika karyawan merasa senang atau gembira atau suka untuk bekerja, maka hasil pekerjaannya pun akan berhasil baik. Demikian pula jika seseorang tidak senang atau tidak suka atas pekerjaanya, maka akan ikut memengaruhi hasil kerja karyawan.

j.Lingkungan kerja Merupakan suasana atau kondisi di sekitar lokasi tempat bekerja. Lingkungan kerja dapat berupa ruangan, layout, sarana dan prasarana, serta hubungan kerja sesama rekan kerja. Jika lingkungan kerja dapat membuat suasana nyaman dan memberikan ketenangan makan akan membuat suasana kerja menjadi kondusif, sehingga dapat meningkatkan hasil kerja seseorang menjadi lebih baik, karena bekerja tanpa gangguan, begitupun sebaliknya.

k. Loyalitas Merupakan kesetiaan karyawan untuk tetap bekerja dan membela perusahaan di mana tempatnya bekerja. Kesetiaan ini ditunjukkan dengan terus bekerja dengan sungguh-sungguh sekalipun perusahaannya dalam kondisi yang kurang baik. Karyawan yang setia juga dapat dikatakan karyawan tidak membocorkan apa yang menjadi rahasia perusahaan kepada pihak lain dan selalu membanggabanggakan perusahaannya pada pihak lain.

1. Komitmen Merupakan kepatuhan karyawan untuk menjalankan kebijakan atau peraturan perusahaan dalam bekerja. Komitmen juga diartikan kepatuhan karyawan kepada janji-janji yang telah dibuatnya. Atau dengan kata lain komitmen merupakan kepatuhan untuk menjalankan kesepakatan yang telah dibuat. Dengan mematuhi janji atau kesepakatan tersebut membuatnya berusaha untuk bekerja dengan baik.

m. Disiplin kerja Merupakan usaha karyawan untuk menjalankan aktivitas kerjanya secara sungguhsungguh. Disiplin kerja dalam hal ini dapat berupa waktu, misalnya masuk kerja tepat waktu, kemudian disiplin dalam mengerjakan apa yang diperintahkan kepadanya sesuai dengan perintah yang harus dikerjakan.

Jadi, dapat disimpulkan untuk meningkatkan kinerja karyawan perlu memperhatikan faktor-faktor penyebab seperti yang telah dikemukakan di atas. Artinya masing-masing variabel akan memberikan kontribusi tersendiri terhadap kinerja. 
2. Tujuan penilaian kinerja

Salah satu fungsi evaluasi yang sangat penting dilakukan adalah dengan melakukan penilaian kinerja karyawan. Kegiatan penilaian kinerja karyawan ini sudah menjadi hal umum khususnya di perusahaan besar.

Sadariah (2016:98) bahwa penilaian prestasi kerja atau kinerja mempunyai tujuan yang berindikator luas, yaitu:

a. Tujuan umum:

1) Penilaian karya atau prestasi bertujuan untuk memperbaiki pekerjaan para pekerja, dengan memberikan bantuan agar setiap pekerja mewujudkan dan menggunakan potensi yang dimilikinya secara maksimal dalam melaksanakan misi organisasi/perusahaan melalui pelaksanaan pekerjaan masingmasing.

2) Penilaian karyawan bertujuan untuk menghimpun dan mempersiapkan informasi bagi pekerja dan para manajer dalam membuat keputusan yang dapat dilaksanakan sesuai dengan bisnis organisasi/perusahaan ditempatnya bekerja.

3) Penilaian karyawan secara umum bertujuan untuk menyusun inventarisasi SDM di lingkungan organisasi atau perusahaan yang dapat digunakan dalam mendesain hubungan antara atasan dan bawahan, guna mewujudkan saling pengertian dan penghargaan dalam rangka mengembangkan

keseimbangan antara keinginan pekerja secara individual dengan sasaran organisasi/perusahaan, dan dari hasil tersebut dapat pula diketahui tentang kepuasan kerja atau sebaliknya. Disamping itu dapat pula digunakan untuk menyusun program pengembangan pribadi, pengembangan karier, program pelatihan, dan lainlain bagi setiap pekerja.

4) Penilaian karyawan bertujuan untuk meningkatkan motivasi kerja yang berpengaruh pada prestasi para pekerja dalam melaksanakan tugas-tugasnya. Untuk itu hasil penilaian perlu diketahui oleh para pekerja. Dari satu sisi pengetahuan tentang keberhasilannya akan menjadi motivasi untuk mempertahankannya dan bahkan untuk meningkatkannya di masa depan. Sebaliknya informasi kegagalan dapat digunakan oleh organisasi atau perusahaan dalam usaha mendorong para pekerja memperbaiki kekurangan atau kelemahannya agar di masa depan kinerjanya lebih meningkat.

b. Tujuan khusus:

1) Penilaian karya bertujuan untuk mendapatkan informasi yang dapat digunakan sebagai dasar melakukan promosi, menghentikan pelaksanaan pekerjaan yang keliru atau tindakan memperbaiki (melaksanakan konseling), menegakkan disiplin sebagai kepentingan bersama, menetapkan pemberian 
penghargaan/balas jasa, dan merupakan ukuran dalam mengurangi atau menambah pekerja melalui perencanaan sumber daya manusia.

2) Penilaian karya bertujuan untuk menghasilkan informasi yang dapat dipergunakan sebagai kriteria dalam membuat tes yang validitasnya tinggi. Dengan kata lain informasi penilaian karya dapat digunakan untuk keperluan rekrutmen dan seleksi, karena dengan tes yang valid akan diperoleh hasil berupa skor (nilai) yang dapat digunakan untuk memprediksi kemampuan calon pekerja dalam mengisi kekosongan, sehingga dapat diperoleh pekerja yang berkualitas.

3) Penilaian karya menghasilkan informasi sebagai umpan balik (feedback) bagi pekerja dalam meningkatkan efisiensi kerjanya, dengan memperbaiki kekurangan atau kekeliruannya dalam melaksanakan pekerjaan. Pekerja yang berstatus bawahan dapat mempergunakan informasi hasil penilaian karya untuk mengembangkan diri masingmasing secara individual.

4) Penilaian karya bertujuan untuk menghasilkan informasi yang dapat dipergunakan untuk mengidentifikasi kebutuhan pekerja dalam meningkatkan kinerjanya, baik yang berkenaan dengan pengetahuan dan keterampilan dalam bekerja maupun yang menyentuh sikap terhadap pekerjaannya. Dengan demikian informasi penilaian karya dapat dipergunakan untuk menetapkan tujuan dan materi di dalam kurikulum pelatihan tenaga kerja.

5) Penilaian karya bertujuan untuk memberikan informasi tentang spesifikasi jabatan, baik untuk pembidangannya maupun perjenjangannya dalam struktur organisasi/perusahaan.

Spesifikasi ini dapat membantu dalam memecahkan masalahmasalah yang terjadi dalam organisasi atau perusahaan dan meminimalisir masalah yang ada.

6) Penilaian karya bertujuan untuk meningkatkan komunikasi sebagai usaha mewujudkan hubungan manusiawi yang harmonis antara atasan dan bawahan, terutama jika penilaian dilakukan dengan metode interview.

\section{Manfaat penilaian kinerja}

Bagi pihak manajemen perusahaan ada banyak manfaat dengan dilakukannya penilaian kinerja. Manfaat yang diperoleh dari penilaian kinerja ini terutama menjadi pedoman dalam melakakukan evaluasi bagi pembentukan organisasi sesuai dengan pengharapan dari berbagai pihak, yaitu baik pihak manajemen serta komisaris perusahaan. Berikut beberapa manfaat penilaian kinerja menurut ahli.

Menurut Fahmi (2017:66) "ada banyak manfaat dengan dilakukannya penilaian kinerja. Penilaian kinerja 
dimanfaatkan oleh manajemen dan menjadi pedoman dalam melakukan tindakan evaluasi bagi pihak manajemen atas kinerja kerja dan produktivitas karyawannya", yaitu:

a. Mengelola operasi organisasi secara efektif dan efesien melalui pemotivasian karyawan secara maksimum

b. Membantu pengambilan keputusan yang bersangkutan dengan karyawan, seperti: promosi, transfer, dan pemberhentian.

c. Mengidentifikasikan kebutuhan pelatihan dan pengembangan karyawan dan untuk menyediakan kriteria seleksi dan evaluasi program pelatihan karyawan.

d. Menyediakan umpan balik bagi karayawan mengenaik bagaimana atasan mereka menilai kinerja mereka.

e. Menyediakan suatu dasar bagi distribusi penghargaan.

\section{Indikator kinerja}

Indikator kinerja atau performance indicators kadang-kadang dipergunakan secara bergantian dengan ukuran kinerja, tetapi banyak pula yang membedakannya. Pengukuran kinerja berkaitan dengan hasil yang dapat dikuantitatifkan dan mengusahakan data setelah kejadian.

Terdapat tujuh indikator kinerja menurut Wibowo (2017:86). Dua diantaranya mempunyai peran yang sangat penting, yaitu tujuan dan motif. Namun kinerja memerlukan adanya hubungan sarana, kompetensi, peluang, standar, dan umpan balik. Berikut penjelasan indikator kinerja tersebut: a)Tujuan; b)Standar; c) umpan Balik; d) Alat atau Sarana; e) Kompetensi; f) Motif; dan g) Peluang.
Pekerja perlu mendapatkan kesempatan untuk menunjukan prestasi kerjanya. Tedapat dua faktor yang menyumbangkan pada adanya kekurangan kesempatan untuk berprestasi, yaitu ketersediaan waktu dan kemampuan memenuhi syarat. Tugas mendapatkan prioritas lebih tinggi, mendapat perhatian lebih banyak, dan mengambil waktu yang tersedia. Jika pekerja dihindari karena supervisor tidak percaya terhadap kualitas atau kepuasan konsumen, mereka secara efektif akan dihambat dari kemampuan memenuhi syarat untuk berprestasi.

\section{Teori Hubungan Gaya Kepemimpinan Dengan Kinerja}

Di dalam suatu perusahaan pada dasarnya mengharapkan kinerja karyawan yang maksimal. Sebab dengan kinerja karyawan yang baik tentu baik pula kinerja perusahaan dan perusahaan dapat mencapai sasaran yang ada. Berhubungan dengan meningkatkan kinerja karyawan yang ada salah satu faktor yang berpengaruh besar terhadap kinerja karyawan yaitu gaya kepemimpinan seseorang. Dengan gaya yang sedemikian rupa mampu menentukan dan berpengaruh pada kinerja karyawan itu sendiri, apakah dengan gaya kepemimpinan yang diterapkan pada suatu perusahaan kinerja karyawan dan kinerja perusahaan akan meningkat atau malah justru mengalami penurunan.

Sadariah (2016:13) "bahwa gaya kepemimpinan yang ditetapkan oleh seorang manajer dalam organisasi dapat menciptakan integrasi yang serasi dan mendorong gairah kerja karyawan untuk mencapai sasaran yang maksimal", dan Sutrisno (2017:233) "bahwa pimpinan perusahaan harus berpedoman pada teori-teori kepemimpinan, sehingga pimpinan di perusahaan memiliki 
kemampuan memengaruhi dan memberikan motivasi kepeada karyawannya, yang berdampak pada peningkatan kinerja”.

Berdasarkan teori dapat disimpulkan bahwa gaya kepemimpinan merupakan sekumpulan ciri atau cara yang digunakan oleh seorang pemimpin untuk mempengaruhi bawahan agar sasaran organisasi dapat tercapai. Oleh sebab itu gaya kepemimpinanlah yang berperan aktif pada keberhasilan organisasi dalam menyelenggarakan berbagai aktifitas terutama terlihat dalam kinerja karyawannya. Hasil yang efektif dan efisien dari seorang pemimpin dapat dilihat dari bagaimana seorang pemimpin itu sendiri mempengaruhi bawahannya, bagaimana pola yang digunakan untuk berkomunikasi dan bekerjasama dengan karyawannya. Sedangkan kinerja karyawan adalah hasil kerja dan tanggung jawab yang telah dicapai dan dilaksanakan oleh karyawan baik secara kualitas ataupun kuantitas.

\section{Hipotesis}

Berdasarkan uraian masalah yang dikemukakan di atas maka dirumuskan hipotesis penelitian yang digunakan "diduga gaya kepemimpinan berpengaruh positif dan signifikan terhadap kinerja karyawan pada
PT. Pelindo IV (Persero) Cabang Makassar".

\section{III.METODE PENELITIAN}

Penelitian ini dilaksanakan di kantor PT. Pelindo IV (Persero) Cabang Makassar, yang beralamat di jalan Soekarno No. 1 Makassar sebagai tempat obyek penelitian. Jenis data yang digunakan adalah data kualitatif dan data kuantitatif. Sumber data yang digunakan yaitu data primer dan sekunder. Metode analisis yang digunakan adalah deskriptif dan regresi linear sederhana, koefisien korelasi, koefisien determinasi, serta uji t.

\section{HASIL PENELITIAN DAN PEMBAHASAN}

\section{Hubungan Gaya Kepemimpinan dengan Kinerja}

Pengaruh gaya kepemimpinan terhadap kinerja pada PT. Pelindo IV (Persero) Cabang Makassar, dapat diketahui dengan menerapkan metode analisis statistik, di mana metode regresi liner sederhana dan koefisien korelasi serta koefisien determinasi, lalu menguji hipotesis bahwa ada tidaknya koefisien korelasi.

Tabel Perhitungan kompenen regresi sederhana

\begin{tabular}{|c|c|c|c|c|c|}
\hline \multirow{2}{*}{ No } & \multicolumn{2}{|c|}{ Gaya Kepemimpinan } & \multicolumn{2}{|c|}{ Kinerja } & \multirow{2}{*}{ XY } \\
\cline { 2 - 5 } & $\mathbf{X}$ & $\mathbf{X}^{\mathbf{2}}$ & $\mathbf{Y}$ & $\mathbf{Y}^{\mathbf{2}}$ & 1849 \\
\hline 1 & 43 & 1849 & 43 & 1849 & 1482 \\
\hline 2 & 38 & 1444 & 39 & 1521 & 1599 \\
\hline 3 & 41 & 1681 & 39 & 1521 & 1482 \\
\hline 4 & 38 & 1444 & 39 & 1521 & 1720 \\
\hline 5 & 43 & 1849 & 40 & 1600 & 1224 \\
\hline 6 & 34 & 1156 & 36 & 1296 & 2021 \\
\hline 7 & 43 & 1849 & 47 & 2209 & 1680 \\
\hline 8 & 42 & 1764 & 40 & 1600 & \\
\hline
\end{tabular}




\begin{tabular}{|c|c|c|c|c|c|}
\hline 9 & 49 & 2401 & 47 & 2209 & 2303 \\
\hline 10 & 43 & 1849 & 44 & 1936 & 1892 \\
\hline 11 & 32 & 1024 & 34 & 1156 & 1088 \\
\hline 12 & 45 & 2025 & 46 & 2116 & 2070 \\
\hline 13 & 46 & 2116 & 39 & 1521 & 1794 \\
\hline 14 & 43 & 1849 & 47 & 2209 & 2021 \\
\hline 15 & 34 & 1156 & 36 & 1296 & 1224 \\
\hline 16 & 46 & 2116 & 43 & 1849 & 1978 \\
\hline 17 & 37 & 1369 & 39 & 1521 & 1443 \\
\hline 18 & 27 & 729 & 29 & 841 & 783 \\
\hline 19 & 42 & 1764 & 40 & 1600 & 1680 \\
\hline 20 & 36 & 1296 & 39 & 1521 & 1404 \\
\hline 21 & 31 & 961 & 35 & 1225 & 1085 \\
\hline 22 & 41 & 1681 & 43 & 1849 & 1763 \\
\hline 23 & 43 & 1849 & 44 & 1936 & 1892 \\
\hline 24 & 48 & 2304 & 50 & 2500 & 2400 \\
\hline 25 & 45 & 2025 & 41 & 1681 & 1845 \\
\hline 26 & 49 & 2401 & 47 & 2209 & 2303 \\
\hline 27 & 44 & 1936 & 46 & 2116 & 2024 \\
\hline 28 & 40 & 1600 & 38 & 1444 & 1520 \\
\hline 29 & 47 & 2209 & 48 & 2304 & 2256 \\
\hline 30 & 40 & 1600 & 40 & 1600 & 1600 \\
\hline 31 & 47 & 2209 & 50 & 2500 & 2350 \\
\hline 32 & 43 & 1849 & 44 & 1936 & 1892 \\
\hline 33 & 40 & 1600 & 39 & 1521 & 1560 \\
\hline 34 & 50 & 2500 & 46 & 2116 & 2000 \\
\hline 35 & 42 & 1764 & 39 & 1521 & 1638 \\
\hline 36 & 48 & 2304 & 47 & 2209 & 2256 \\
\hline 37 & 30 & 900 & 33 & 1089 & 990 \\
\hline 38 & 41 & 1681 & 42 & 1764 & 1722 \\
\hline 39 & 41 & 1681 & 38 & 1444 & 1558 \\
\hline 40 & 42 & 1764 & 44 & 1936 & 1848 \\
\hline 41 & 48 & 2304 & 45 & 2025 & 2160 \\
\hline 42 & 40 & 1600 & 38 & 1444 & 1520 \\
\hline 43 & 35 & 1225 & 37 & 1368 & 1295 \\
\hline 44 & 47 & 2209 & 45 & 2025 & 2115 \\
\hline 45 & 47 & 2209 & 44 & 1936 & 2068 \\
\hline
\end{tabular}




\begin{tabular}{|c|c|c|c|c|c|}
\hline 46 & 46 & 2116 & 44 & 1936 & 2024 \\
\hline 47 & 45 & 2025 & 44 & 1936 & 1980 \\
\hline 48 & 50 & 2500 & 50 & 2500 & 2500 \\
\hline 49 & 43 & 1849 & 44 & 1936 & 1892 \\
\hline 50 & 33 & 1089 & 34 & 1156 & 1122 \\
\hline 51 & 36 & 1296 & 38 & 1444 & 1368 \\
\hline 52 & 40 & 1600 & 40 & 1600 & 1600 \\
\hline 53 & 38 & 1444 & 38 & 1444 & 1444 \\
\hline 54 & 32 & 1024 & 35 & 1225 & 1120 \\
\hline 55 & 37 & 1369 & 39 & 1521 & 1443 \\
\hline 56 & 39 & 1521 & 42 & 1764 & 1638 \\
\hline 57 & 43 & 1849 & 42 & 1764 & 1806 \\
\hline 58 & 44 & 1936 & 40 & 1600 & 1760 \\
\hline 59 & 50 & 2500 & 45 & 2025 & 2250 \\
\hline 60 & 49 & 2401 & 50 & 2500 & 105094 \\
\hline$\sum$ & 2496 & 105614 & 2494 & 104942 & \\
\hline
\end{tabular}

Sumber: Data diolah, 2020

1. Analisis Regresi Linear

Untuk menguji pengaruh gaya kepemimpinan terhadap kinerja karyawan, maka digunakan analisis regresi linear. Berikut bentuk persamaannya:

$y=a+b x$

Dan untuk mendapatkan persamaannya, maka nilai a dan $b$ harus ditentukan dengan menggunakan rumus sebagai berikut :

$$
\begin{aligned}
b & =\frac{n\left(\sum X Y\right)-(\Sigma X)(\Sigma Y)}{n\left(\Sigma X^{2}\right)-(\Sigma X)^{2}} \\
a & =\frac{\sum Y}{n}-\frac{b \sum X}{n} \\
b & =\frac{60(105094)-(2496)(2494)}{60(105614)-(2496)^{2}} \\
a & =\frac{2494}{60}-\frac{0,754(2496)}{60} \\
b & =\frac{6305640-6225024}{6336840-6230016} \\
a & =\frac{2494-1881,984}{60} \\
b=\frac{80616}{106824} &
\end{aligned}
$$

$$
\begin{gathered}
a=\frac{612,016}{60} \\
b=0,754 \\
a=10,200
\end{gathered}
$$

Dari perhitungan di atas, maka didapatkan persamaan regresi linear sederhana antara variabel $\mathrm{x}$ dan y adalah :

$y=10,200+0,754 X$

Dari persamaan diatas dapat dijelaskan sebagai berikut:

a. nilai . $a=10,200$, artinya apabila

variabel gaya kepemimpinan sama dengan nol (tidak berubah), maka kinerja karyawan sebesar 10,200.

b. Nilai gaya kepemimpinan (x) 0,754, artinya setiap terjadi perubahan variabel gaya kepemimpinan (x) sebesar 1 satuan diharapkan akan meningkatkan kinerja karyawan (y) sebesar 0,754 . 
2. Analisis Koefisien Korelasi

Regresi linear sederhana bertujuan untuk mengetahui keterkaitan antara variabel secara umum, sedangkan koefisien korelasi $(r)$ bertujuan untuk mengetahui seberapa erat keterkaitannya dengan nilai signifikan.

Untuk mengetahui gaya kepemimpinan terhadap kinerja karyawan maka komponen-komponen di atas dimasukkan ke dalam persamaan koefisien korelasi $(r)$, yaitu:

$$
\mathrm{r}=\frac{n \sum X Y-\sum X \sum Y}{\sqrt{n \sum X^{2}-\left(\sum X\right)^{2}} \sqrt{n \sum Y^{2}-\left(\sum Y\right)^{2}}}
$$$$
r=\frac{60(105094)-(2496)(2494)}{\sqrt{60(105614)-(2496)^{2} \cdot 60(104092)-(2494)^{2}}}
$$$$
r=\frac{6305640-6225024}{\sqrt{(6336840-6230016)(6296520-6220036)}}
$$

$$
r=\frac{80616}{\sqrt{(106824)(76484)}}
$$

$$
r=\frac{80616}{90389,86014}
$$

$r=0,891$

Dari hasil analisis di atas diperoleh nilai koefisien korelasi 0,891 berada pada 0,81 - 1,00 dengan korelasi sangat kuat, sehingga dapat disimpulkan bahwa terdapat hubungan yang sangat kuat antara variabel gaya kepemimpinan dan variabel kinerja pada karyawan PT. Pelindo IV (Persero) Cabang Makassar.

3. Koefisien Determinasi

Berikut bentuk rumus dan perhitungan yang diterapkan untuk mengetahui pengaruh gaya kepemimpinan terhadap kinerja karyawan PT. Pelindo IV (Persero) Cabang Makassar (koefisien determinasi):

$$
\begin{aligned}
& =r^{2} \times 100 \% \\
& =(0,891)^{2} \times 100 \% \\
& =0,79 \times 100 \% \\
& =79 \%
\end{aligned}
$$

Hasil dari perhitungan determinasi $\left(r^{2}\right)$ adalah 0,79 ini berarti bahwa variabel gaya kepemimpinan mampu menjelaskan variabel kinerja sebesar 79\%. Dan sisanya 21\% dipengaruhi oleh faktor-faktor lain yang tidak diteliti penulis.

4. Pengujian Hipotesis (uji-t)

Hipotesis dapat dibuktikan dan diuji baik atau tidaknya pengaruh gaya kepemimpinan terhadap kinerja karyawan PT. Pelindo IV (Persero) Cabang Makassar, yaitu dengan uji statistik melalui uji-t

$$
t=\sqrt[r]{\frac{n-2}{1-r^{2}}}
$$

$\mathrm{H}_{0}: r \leq 0$, artinya jika $\mathrm{H}_{\mathrm{o}}$ diterima dan $\mathrm{H}_{\mathrm{a}}$ ditolak maka tidak ada pengaruh positif gaya kepemimpinan terhadap kinerja karyawan pada PT. Pelindo IV (Persero) Cabang Makassar.

$\mathrm{H}_{\alpha}: r>0$, artinya jika $\mathrm{H}_{\mathrm{o}}$ ditolak dan $\mathrm{H}_{\mathrm{a}}$ diterima maka ada pengaruh positif antara gaya kepemimpinan terhadap kinerja karyawan pada PT. Pelindo IV (Persero) Cabang Makassar.

Dari perhitungan koefisien korelasi di atas, diketahui:

Nilai koefisien korelasi $(\mathrm{r})=0,891$, taraf nyata $(r)=0,05=5 \%$

Nilai tabel memiliki derajat sebesar (db) $=\mathrm{n}-2$ 


$$
=60-2
$$$$
=58
$$

Maka, $\mathrm{t}_{\text {tabel }} \quad(0,05: 58)=1,671$ (lihat lampiran t-tabel)

$$
\begin{aligned}
T_{\text {hitung }} & =\sqrt[r]{\frac{n-2}{1-r^{2}}} \\
& =\sqrt[0,891]{\frac{60-2}{1-(0,891)^{2}}} \\
& =\sqrt[0,891]{\frac{58}{1-0,793}} \\
& =\sqrt[0,8911]{\frac{58}{0.207}} \\
& =\sqrt[0,891]{280,19} \\
& =
\end{aligned}
$$

$0.891 \times 16,738=14,913$
Pengujian statistik koefisien korelasi dijabarkan dalam rumus tersebut, dengan derajat bebas $(\mathrm{db})=58$, dan taraf nyata 0,05 $(5 \%)$ di atas diperoleh $t_{\text {hitung }}=14,913$, karena $t_{\text {hitung }}=14,913>\mathrm{t}$-tabel 1,671 maka dapat diketahui bahwa $\mathrm{H}_{\mathrm{o}}$ ditolak dan $\mathrm{H}_{\mathrm{a}}$ diterima. Yang berarti terdapat pengaruh positif dan signifikan antara gaya kepemimpinan terhadap kinerja karyawan. Yakni setiap gaya kepemimpinan yang tepat akan memberikan kerja yang maksimal bagi suatu perusahaan akan dapat mempengaruhi kinerja karyawan.

Hasil perhitungan tersebut digambarkan sebagai berikut:

Gambar Grafik uji statistik koefisien korelasi

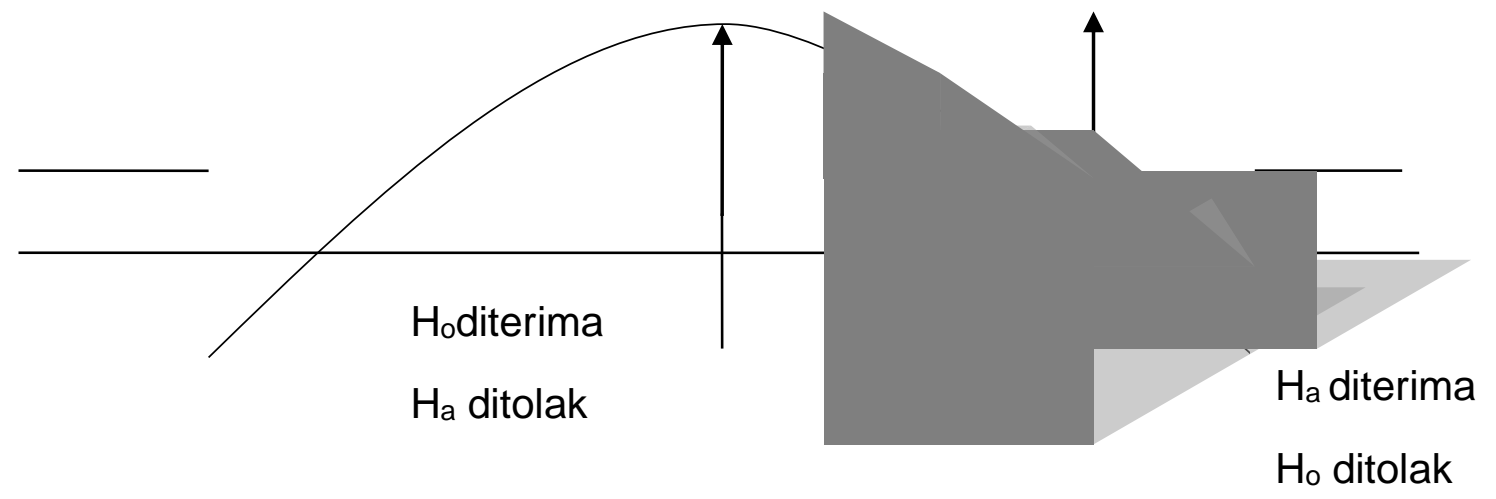

$0 \quad t_{\text {tabel }} 1,671$

$\mathrm{t}_{\text {hitung }} 14,913$

Sumber: Data diolah, 2020

Dari gambar tersebut dapat dilihat bahwa nilai $t_{\text {hitung }}=14,913$, karena $t_{\text {hitung }}>$ $\mathrm{t}_{\text {tabel }}(14,913>1,671)$, maka telah diketahui bahwa $\mathrm{H}_{\mathrm{o}}$ ditolak dan $\mathrm{H}_{\mathrm{a}}$ diterima. Dengan demikian, hipotesis yang menyatakan bahwa gaya kepemimpinan mempunyai pengaruh positif dan signifikan terhadap kinerja karyawan dapat diterima. Hasil penelitian ini didukung oleh penelitian terdahulu, yaitu: Rama Saputra Salam (2016) dengan judul "Pengaruh Gaya Kepemimpinan Terhadap
Kinerja Karyawan Pada PT. Eastern Pearl Flour Mills Makassar". Perhitungan regresi sebesar $\mathrm{y}=55,712+0,60391 \mathrm{x}$, koefisien korelasi $(\mathrm{r})=0,58$, koefisien determinasi $\left(r^{2}\right)$ $=34 \%$, hasil perhitungan uji-t dimana $\mathrm{t}-$ hitung $>$ t-tabel yaitu 5,095>1,293. Dan Andi Abdullah Rivai (2018) dengan judul "Pengaruh Gaya Kepemimpinan Terhadap Kinerja Karyawan Departemen Plant PT. Japfa Comfeed Indonesia, Tbk. Makassar". Perhitungan regresi sebesar y $=17,5+$ $0,596 \mathrm{x}$, nilai koefisien korelasi $(\mathrm{r})=0,57$ 
dan koefisien determinasi $\left(r^{2}\right)=32 \%$, hasil perhitungan uji-t dimana $t$-hitung $>t$-tabel yaitu $6,05>1,992$.

Sutrisno (2017:233) "bahwa pimpinan perusahaan harus berpedoman pada teori-teori kepemimpinan, sehingga pimpinan di perusahaan memiliki kemampuan memengaruhi dan memberikan motivasi kepeada karyawannya, yang berdampak pada peningkatan kinerja".

\section{KESIMPULAN DAN SARAN}

\section{A. Kesimpulan}

Dari hasil penelitian dan analisis serta pembahasan pada bab sebelumnya, didapatkan kesimpulan mengenai penelitian ini, yaitu gaya kepemimpinan terhadap kinerja pada PT. Pelindo IV (Persero) Cabang Makassar, dengan melakukan perbandingan antara skor aktual dan skor ideal dapat disimpulkan bahwa pengaruh gaya kepemimpinan pada karyawan mencapai persentase $83 \%$ atau termasuk kriteria sangat baik, sedangkan kinerja karyawan juga mencapai persentase $83 \%$ atau termasuk kriteria yang sangat baik.

Lalu penulis melakukan analisis menggunakan statistika, maka diperoleh regresi $(y)=10,200+0,754 x$ dan koefisien korelasi $(r)=0,891$ yang berarti variabel gaya kepemimpinan dan variabel kinerja kerja terdapat korelasi hubungan yang sangat kuat, sedangkan koefisien determinasi $\left(r^{2}\right)$ diperoleh 0,79 atau $79 \%$ dan sisanya $21 \%$ dipengaruhi oleh faktorfaktor yang lain. Perhitungan uji-t didapatkan hasil $t_{\text {hitung }}>t_{\text {tabel }}(14,913>1,671)$ maka diketahui bahwa $\mathrm{H}_{\mathrm{o}}$ ditolak dan $\mathrm{H}_{\mathrm{a}}$ diterima. Hasil penelitian menunjukkan terdapat hubungan positif dan signifikan antara gaya kepemimpinan terhadap kinerja karyawan PT. Pelindo IV (Persero) Cabang
Makassar, dengan demikian hipotesis yang diajukan penulis diterima.

\section{B. Saran}

Adapun saran yang penulis dapat sampaikan sehubungan dengan hasil penelitian dan kesimpulan, yakni: Penulis berharap para pemimpin yang ada di PT. Pelindo IV (Persero) Cabang Makassar dapat memperbaiki kepribadiannya masingmasing, karena dari hasil penelitian banyak responden menanggapi secara positif bahwa kepribadian pemimpin akan menjadi penentu keberhasilan pemimpin itu sendiri. Sedangkan saran penulis agar kinerja karyawan terus meningkat, pihak manajemen PT. Pelindo IV (Persero) Cabang Makassar tetap memperhatikan alat atau sarana untuk pekerjaan spesifik mereka, agar tidak terjadi penurunan kinerja dari para karyawannya.

\section{DAFTAR PUSTAKA}

1) Fahmi, Irham. 2017. Manajemen Kepemimpinan Teori \& Aplikasi. Bandung: CV Alfabeta.

2) Hasibuan, Malayu, SP. 2017. Manajemen Sumber Daya Manusia edisi revisi. Jakarta: Bumi Aksara.

3) Kartono, Kartini. 2018. Pemimpin dan Kepemimpinan. Jakarta: PT. RajaGrafindo Persada.

4) Kasmir. 2016. Manajemen Sumber Daya Manusia Cet 2. Jakarta: PT. RajaGrafindo Persada.

5) Mangkunegara, Anwar Prabu. 2017. Evaluasi Kinerja SDM. Bandung: PT. Refika Aditama.

6) Sadariah. 2016. Menjadi Pemimpin Sejati Dari Teori Ke Praktek Dalam Perspektif Perubahan. Makassar: CV. Bintang Selatan. 
7) Sugiyono. 2012. Metode Penelitian Kuantitatif, Kualitatif, dan $R \& D$. Bandung: Alfabeta CV.

8) Sujarweni, Wiratna. 2014. Metodologi Penelitian. Yogyakarta: PustakaBaruPress.
9) Sutrisno, Edy. 2017. Manajemen Sumber Daya Manusia cetakan ke-9. Jakarta: Kencana.

10) Thoha, Miftah. 2017. Kepemimpinan Dalam Manajemen cetakan ke-19. Depok: PT. RajaGrafindo Persada.

11) Wibowo. 2017. Manajemen Kinerja. Depok: PT. RajaGrafindo Persada. 